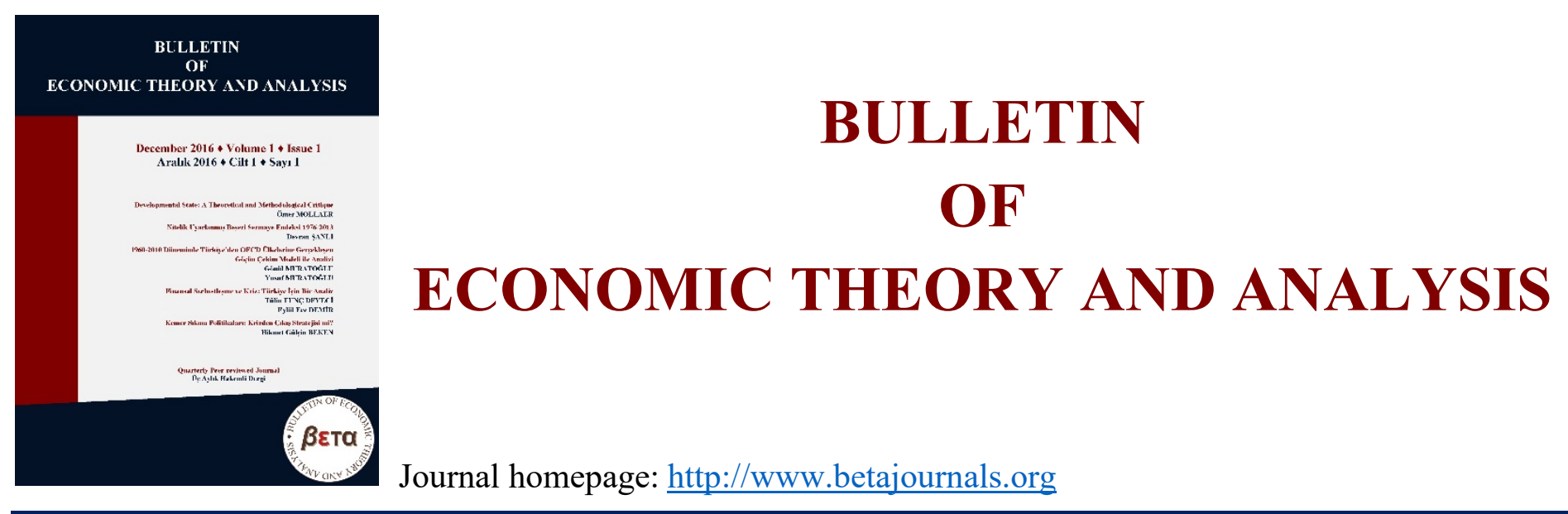

\title{
An Analysis of the Relationship between Inflation and Gold Prices: Evidence from Turkey
}

\section{Mortaza OJAGHLOU ๑ https://orcid.org/0000-0003-4580-6182}

\section{Rozita SATVATI $\odot$ https://orcid.org/0000-0003-1329-8443}

To cite this article: Ojaghlou, M., \& Satvati, R. (2021). An Analysis of the Relationship between Inflation and Gold Prices: Evidence from Turkey. Bulletin of Economic Theory and Analysis, 6(2), 79-89.

Received: 13 Oct 2021

Accepted: 20 Dec 2021

Published online: 31 Dec 2021

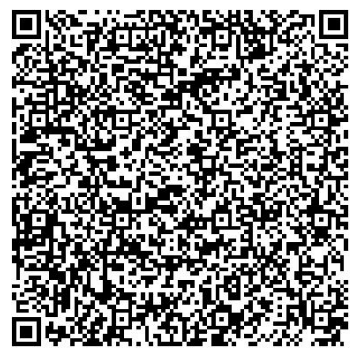




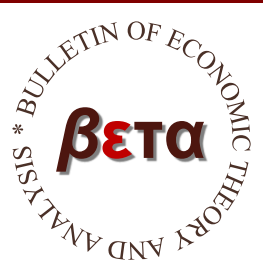

\title{
Bulletin of Economic Theory and Analysis
}

\author{
Volume V, Issue 2, pp. 79-89, 2021 \\ http://www.betajournals.org
}

Original Article / Araştırma Makalesi

Received / Alınma: 13.10.2021 Accepted / Kabul: 09.12.2021

\section{An Analysis of the Relationship between Inflation and Gold Prices: Evidence from Turkey}

\author{
Mortaza OJAGHLOU ${ }^{\mathrm{a}}$ \\ Rozita SATVATI ${ }^{\mathrm{b}}$
}

\footnotetext{
${ }^{a}$ Assist. Prof. Dr., Istanbul Aydin University, FEAS, Department of Economics, Istanbul, TURKEY

(2) https://orcid.org/0000-0003-4580-6182

${ }^{\mathrm{b}}$ Istanbul Aydin University, Istanbul, TURKEY

(2) https://orcid.org/0000-0003-1329-8443
}

\begin{abstract}
In this paper, we examine the short and long run dynamic relationship between inflation (consumer price index) and the price of gold in Turkey by using monthly data over the period of $2008 \mathrm{~m} 10-2021 \mathrm{~m} 04$. The finding shows there is no long run and cointegration between consumer price index and the price of gold in Turkey. However, the results demonstrate that CPI does Granger cause of gold but gold dose not Granger cause of CPI. Those results are also confirmed by results of short-run of S-model and the long-run properties of the accumulated impulse responses of structural VAR (SVAR) model that there is not long run interaction between gold and inflation.
\end{abstract}

Keywords Gold Prices, Inflation, Cointegration, Hedge

JEL Classification C22, C52, G15, Q02

CONTACT Mortaza OJAGHLOU $₫$ mortazaojaghlou@aydin.edu.tr $\risingdotseq$ Istanbul Aydin University, FEAS, Department of Economics, Istanbul, TURKEY 


\section{Introduction}

Gold prices have historically become to be a strong leading indicator in many countries and compared to other inflation indicators gold remains statistically significant (Tkacz, 2007). Bretton Woods system in 1971 and the transition of the United States of America from a goldlinked currency to legal tender was what attracted academia and professional to the U.S. financial Market. Regardless of Bretton Woods system, gold has historically long been the commodity most closely characterized and identified with money. Even gold and money have often been considered being essentially the same thing. Although Collapse of Bretton Woods System in 1971, gold still has a significant role as a real commodity and asset to affect macroeconomics indicators. However, gold's ability as hedge for inflation a protector of finance is still controversial. The studies such as (Jastram, 1977) and (Jastram \& Leyland, 2009) show that gold price remind stable during centuries. While, (Chua \& Woodward, 1982) conducted to estimate the long run relationship between inflation (CPI) and price of gold for Switzerland, the United States of America, Japan, the United Kingdom, Canada, and Germany over the period 1975-1980. The finding indicated that gold was a hedge against inflation only in the United States of America. The studies such as (Baur \& McDermott, 2010), (Narayan et al., 2013) and (Narayan et al., 2010) emphasis that most countries gold is considered as a profitable and investment tools. According to research of Amundi asset management because of using gold as reserve asset in many central banks, gold would remain an important element of global monetary reserves system and this study estimate that role of gold would be more important in future.

The literature review shows that there are two main approaches about the relationship between gold and inflation. The first approach is that how inflation affects gold's prices and the other one is an approach based on effects of gold price on inflation or whether gold is a hedge against inflation or not.

Example for first approach is study of (Batten et al., 2014). They show that there is no cointegration between gold and inflation (consumer price index (CPI)) and they finding suggests that gold's sensitivity to inflation is associated to interest rate. (Sharma, 2016) found evidence that the CPI (consumer price index) has ability to predict changes in gold prices in the United Kingdom, the United States, and various other countries and regions. (Sharma, 2016) studied the ability of 54 countries' CPI to predict the price of gold quoted in US dollars. According to this study, UK's 
CPI can predict the price of gold, and the results observed for the US's are mixed, while the study does not find any evidence for Japan. These researches suggest that a more general approach, with respect to gold prices and inflation relationship, must be adopted rather than just a speculation of the impact of one variable on another. Therefore, this work has contributed crucially regarding the continuous study of the relationship between gold and inflation. In additional study of (Kalsum et al., 2021) shows that there are a weak and negative relationship between inflation, interest rates, world oil prices and the exchange rate and gold prices.

Example for second approach is studies such as (Moore, 1990) points out that the price of gold can be affected by what the market observation of inflation rate. (Mahdavi \& Zhou, 1997) applied to the same analysis that the gold acts as a leading indicator of the inflation rate. They also applied a formal test of temporal changes, and investigated that the relationship between two variables was broken and they stress on money supply effect related to their hypostases. (Hoang et al., 2016) shows that in the long run, gold is not a hedge against inflation, they found a shortterm hedge in the United States and the United Kingdom. They argue that gold can hedge the money supply and inflation hedging ability is incomplete. The price of gold is consistent with the official CPI and exchange rate. (Lucey et al., 2017) used formal test of time variation and time varying cointegration relationships. They finding shows that there is time-varying relationship in cointegration between gold and inflation in almost all case of studies. Also, they find evidence for rules of money supply to gold and inflation relationship. (Iqbal, 2017) results show that gold is a hedge against inflation only in the US. He found partly same results for India but there was no evidence that gold can be a hedge against inflation. (Bampinas \& Panagiotidis, 2015) analyzes the long-run hedging ability of two major metal commodity (gold and silver) prices against consumer price index for United States and the United Kingdom. They used a dataset more than two centuries by using time-invariant and time-varying cointegration methodology. They find that gold has ability to hedge expected and core CPI in the long-run. In additional (Sui et al., 2021) conducts a study on gold's hedging capability against adverse chances of exchange rate and inflation. They consider Turkey as high dollarized, Peru as low dollarized and US as benchmark country. The results show that gold has protection roles against movements or devaluation of currency at all time for Turkey and United States, But fail to do so during Turkey's hyperinflationary period. Also (Xu et al., 2021) finding show that gold has generally keep its purchasing power during the last 39 years and they noted that gold is a reliable hedge against inflation in both short and long run. 


\section{Materials and Methodology}

Following the (Hoang et al., 2016), (Lucey et al., 2017), (Anandasayanan et al., 2019), and (Ojaghlou, 2020) we consider CPI as Proxy for inflation and following to those studies, a brief description of the baseline model is as follows:

$\operatorname{Gold}_{T L}=\alpha_{0}+\alpha_{1} P_{T R}+\varepsilon_{0}$

Where gold price in Turkey (1 Ounce Gold in Turkey Sale Price (Turkish Lira/Ounce), $P_{T R}$ is consumer price index (Consumer Price Index (General)), alfa is constant and epsilon is residual of the regression. For first approach of effect of gold price on price level of Turkey we estimate $\mathrm{eq}(2)$ which is as follows:

$P_{T R}=\beta_{0}+\beta_{1}$ Gold $_{T L}+\gamma_{0}$

Figure 1 shows log of data and the base of 100 is fixed at the beginning of the study period (2008m01).

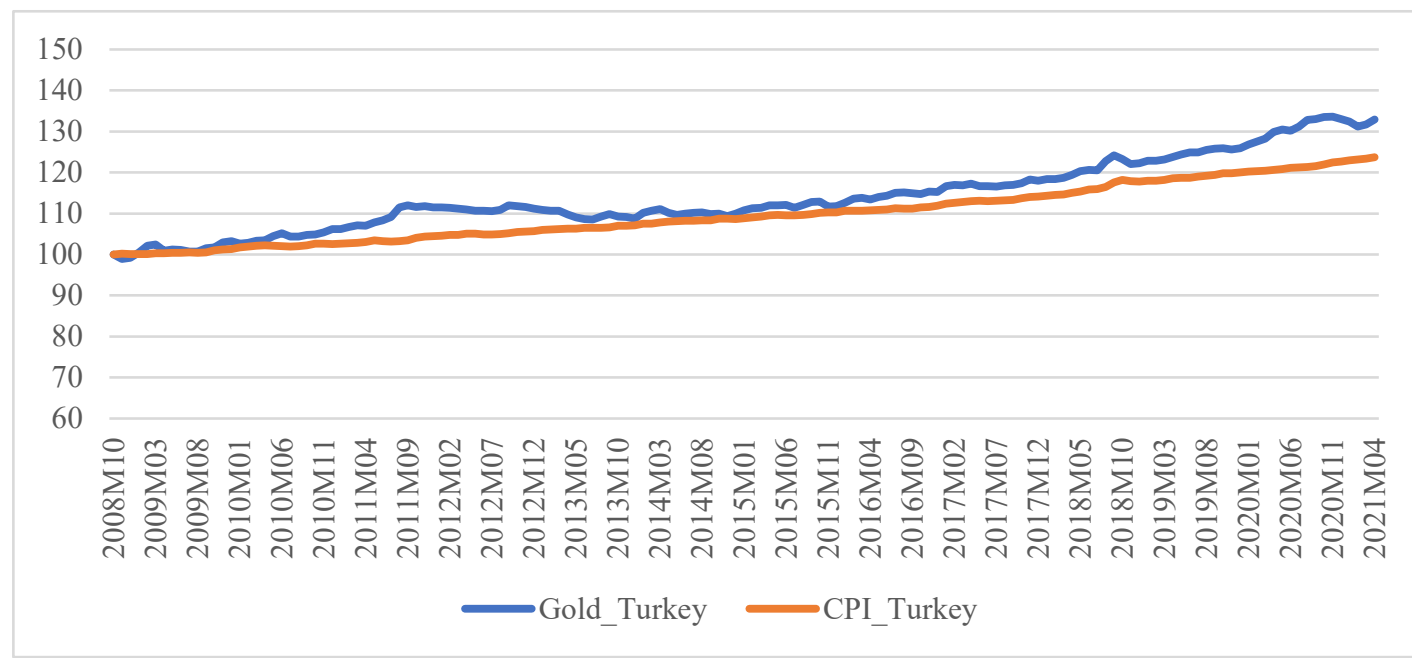

Figure 1. One-Ounce Gold in Turkey Sale Price (Turkish Lira/Ounce) Vs. Consumer Price Index in Turkey (log of data and the base of 100 is fixed)

Table 1

Unit Root Test Results 


\begin{tabular}{|c|c|c|c|c|}
\hline \multirow{2}{*}{ Variable } & \multicolumn{2}{|r|}{$\mathrm{ADF}^{1}$} & \multicolumn{2}{|r|}{$\mathbf{P P}^{2}$} \\
\hline & Intercept & Intercept and trend & Intercept & Intercept and trend \\
\hline Gold Price & $2.62(2)$ & $0.54(2)$ & $2.47(3)$ & $0.29(3)$ \\
\hline$\Delta$ Gold Price & $-8.04(1) * * *$ & $-8.68(1) * * *$ & $-7.38(4) * * *$ & $-7.34(7) * * *$ \\
\hline CPI & $5.22(4)$ & $2.25(4)$ & $7.05(6)$ & $2.02(6)$ \\
\hline$\Delta \mathrm{CPI}$ & $-2.91(4) * *$ & $-6.61(3) * * *$ & $-7.32(4) * * *$ & $-8.75(5) * * *$ \\
\hline
\end{tabular}

Note. The signs $*, * *$ and $* * *$ represent $10 \%, 5 \%$, and less than $1 \%$ significance level, respectively and parenthesis show the optimum number of lags.

According to results of unit root test both of the variables are stationary at first differences I(1). By considering results of TABLE I, (unit root) for cointegration test, we applied to (Engle \& Granger, 1987) cointegration test. For cointegration analysis Engle and Granger suggested twostep procedure. The first one is estimating long-run equation: (in our case: Gold $_{T L}=\alpha_{0}+\alpha_{1} P_{T R}+\varepsilon_{0}(\mathrm{Eq} 1)$ and $P_{T R}=\beta_{0}+\beta_{1}$ Gold $\left._{T L}+\gamma_{0} \quad(\mathrm{Eq} 2)\right)$. The OLS residuals from (Eq1) and (Eq2) are a measure of deviations: $\widehat{\varepsilon_{0}}$ and $\widehat{\gamma_{0}}$ (estimated $\gamma$ and $\varepsilon$ ):

$$
\hat{\varepsilon}_{0}=\operatorname{gold}_{T L}-\hat{\alpha}_{0}-\hat{\alpha}_{1} P_{T R} \text { and } \hat{\gamma}_{0}=P_{T R}-\hat{\beta}_{0}-\hat{\beta}_{1} \text { Gold }_{T R}
$$

Cointegration test is a test of whether $\widehat{\varepsilon_{0}}$ and $\widehat{\gamma_{0}}$ are stationary or not that generally determined by $\mathrm{ADF}$ and PP tests on the $\widehat{\varepsilon_{0}}$ and $\widehat{\gamma_{0}}$ and compering value with the MacKinnon (1991) critical values. The second step is estimating the Error Correction Term and model (ECT) which in our case can be written as:

$$
\begin{aligned}
& \Delta \operatorname{Gold}_{T L}=\lambda_{0}+\sum_{j=1} \lambda_{j} \Delta \operatorname{Gold}_{T L, t-j}+\sum_{i=0} \varphi_{1} \Delta P_{T L, t-i}+\sigma \hat{u}_{t-1}+\varepsilon_{t} \\
& \Delta P_{T L}=\phi_{0}+\sum_{j=1} \phi_{j} \Delta P_{T L, t-j}+\sum_{i=0} \mu_{1} \Delta \operatorname{Gold}_{T L, t-i}+\vartheta \hat{\psi}_{t-1}+v_{t}
\end{aligned}
$$

By testing OLS, the adjustment coefficient of the model $\left(\mathrm{ECT}_{-1}\right)$ must be between -1 and 0. Error Correction term shows how dependent variable and independent variables behave in the short run consistent with a long run cointegrating relationship. The Table 2 shows estimated of related coefficient:

\footnotetext{
${ }^{1}$ Based on AIC

${ }^{2}$ Based on Bartlett Kernel
} 
Table 2

Estimating of Eq1 and Eq2 and Cointegration Test

\begin{tabular}{|c|c|c|}
\hline Dependent Variables & $\begin{array}{c}\text { eq1 } \\
\text { Gold }_{T L}=\alpha_{0}+\alpha_{1} P_{T L}+\varepsilon_{0}\end{array}$ & $\begin{array}{c}\text { eq2 } \\
P_{T L}=\beta_{0}+\beta_{1} \text { Gold }_{T L}+\gamma_{0}\end{array}$ \\
\hline Constant & $\begin{array}{c}-4305.7 * * * \\
(-16.85)\end{array}$ & $\begin{array}{c}150.34 * * * \\
(36.92)\end{array}$ \\
\hline$\alpha_{1}$ & $\begin{array}{c}31.61 * * * \\
(36.96)\end{array}$ & - \\
\hline$\beta_{1}$ & - & $\begin{array}{c}0.028 * * * \\
(34.36)\end{array}$ \\
\hline $\begin{array}{l}\text { Step 1: } \\
\text { (ADF test for } \widehat{\varepsilon_{0}} \text { and } \widehat{\gamma_{0}} \text { ) }\end{array}$ & $\begin{array}{l}\text { t-Statistic for } \widehat{\varepsilon_{0}}=-1.52 \\
\text { (is not stationary at } \mathrm{I}(0) \text { ) }\end{array}$ & $\begin{array}{l}\text { t-Statistic for } \widehat{\gamma_{0}}=-1.81 \\
\text { (is not stationary at } \mathrm{I}(0) \text { ) }\end{array}$ \\
\hline Step $^{3} 2:$ & $0.006 * * *$ & $0.00005^{* * *}$ \\
\hline ECT-1 & $(4.11)$ & (3.24) \\
\hline$\chi_{\text {Serial }}^{2} 4$ & 141.45 & 141.43 \\
\hline$\chi_{R E S E T, A R C H}^{2}$ & 273.26 & 109.72 \\
\hline
\end{tabular}

Note. $* * *$ Significant at $1 \%$.

As Table 2 shows, the residual of the both regression are not stationary at $\mathrm{I}(0)$ and also the size of ECT $_{-1}$ is not in accepted range of -1 and 0 . Thus, according to Engle-Granger Cointegration methodology there is no log run relationship between variable. In addition, we use 5 lag as optimum lag for ECM that Table 3 shows optimum lag selected criteria:

Table 3

Lag Order Selected for Error Correlation Model

\begin{tabular}{lcccc}
\hline Lag & $\begin{array}{c}\text { Akaike information } \\
\text { criterion }\end{array}$ & $\begin{array}{c}\text { Schwarz } \\
\text { information } \\
\text { criterion }\end{array}$ & $\begin{array}{c}\text { Hannan-Quinn } \\
\text { information } \\
\text { criterion }\end{array}$ & $\begin{array}{c}\text { Final prediction } \\
\text { error }\end{array}$ \\
\hline 0 & 28.88816 & 28.9296 & 28.905 & $1.21 \mathrm{E}+10$ \\
1 & 19.14623 & 19.27054 & 19.19674 & 708203.4 \\
2 & 18.81018 & $19.01737^{*}$ & 18.89437 & 506097.1 \\
3 & 18.76767 & 19.05774 & 18.88554 & 485081.2 \\
4 & 18.73026 & 19.1032 & 18.8818 & 467350.6 \\
5 & $18.69060^{*}$ & 19.14642 & $18.87583^{*}$ & $449304.8^{*}$ \\
6 & 18.71587 & 19.25457 & 18.93477 & 460986.1 \\
7 & 18.72027 & 19.34185 & 18.97285 & 463271.3 \\
8 & 18.75724 & 19.4617 & 19.0435 & 481060.2 \\
\hline
\end{tabular}

Note. * indicates lag order selected by the criterion.

${ }^{3}$ Optimum lag is 5.

${ }^{4}$ Ther is problem of autocorrelation 
According to Engle-Granger cointegration method there is no any long run relationship between variables. Based on stationary level of variable which they are stationary at I (1) and clear understanding of relationship we apply to Johansen-Jealous cointegration methodology to check our hypostasis with different methodology. Table 4 shows results of Johansen-Jealous cointegration method.

Table 4

Johansen-Juselius Cointegration Test Results and VECM ${ }^{5}$

\begin{tabular}{cccccc}
\hline \multirow{2}{*}{$\begin{array}{c}\text { Null } \\
\text { hypothesis }\end{array}$} & Eigenvalue & \multicolumn{2}{c}{ Trace } & \multicolumn{2}{c}{ Maximum Eigenvalue } \\
\cline { 3 - 6 } & & $J_{\text {trace }}$ & $\begin{array}{c}\text { Critical } \\
\text { Value }\end{array}$ & $\boldsymbol{J}_{\text {max }}$ & $\begin{array}{c}\mathbf{0 . 0 5} \\
\text { Critical } \\
\text { Value }\end{array}$ \\
\hline $\mathrm{H} 0: \mathrm{r}=0$ & 0.146 & $24.57^{* * *}$ & 15.49 & $23.02 * * *$ & 14.26 \\
$\mathrm{H} 0: \mathrm{r} \leq 1$ & 0.010 & 1.54 & 3.84 & 1.54 & 3.84 \\
\hline
\end{tabular}

According to Table 4; Considering the trace and eigenvalue statistics, one cointegration vector has been determined, and the Cointegrating equation of VECM is given below:

$\Delta$ Gold $_{T R, t}=0.006 \times\left(\right.$ Gold $_{-1}+198.65$ CPI $\left._{-1}-60667.7\right)$

$+0.46 \times \Delta$ Gold $_{T R,-1}-0.28 \times \Delta$ Gold $_{T R,-2}+0.2 \times \Delta$ Gold $_{T R,-3}$

$-0.19 \times \Delta$ Gold $_{T R,-3}-0.06 \Delta$ Gold $_{T R,-5}+34.4 \times \Delta C P I_{T R,-1}$

$-4.06 \Delta C P I_{T R,-2}-7.82 \Delta C P I_{T R,-3}+5.3 \Delta C P I_{T R,-4}-8.93 \Delta C P I_{T R,-5}+203.01$

As Cointegrating equation shows the ECT-1 is 0.006 that is not within the accepted range of -1 and 0 and it is not negative indicate that speed of adjustment of any disequilibrium cannot adjust in the long-run equilibrium state. We got the same results that there is no long run relationship between variables. We estimate short run relationship of the Eq1 and Eq2 by testing of regression by taking first difference:

$$
\begin{aligned}
\Delta \text { Gold }_{T L}=17.04+28.05 \Delta C P I_{T L} \\
\\
(0.56)^{6} \quad(3.71) \\
\Delta C P I_{T L}=2.22+0.003 \Delta \text { Gold }_{T L}
\end{aligned}
$$

According to (6) and (7) there is positive short run relationship between gold price and

\footnotetext{
${ }^{5}$ There is no autocorrelation problem $\left(\chi_{\text {Serial }}^{2}=3.75\right)$

${ }^{6}$ Paranthesis
} 
inflation in Turkey. In additional according, the Granger Causality there is a causality from inflation to gold price. Below formula shows, Granger Causality of our models and Table 5 shows the results of Granger Causality test:

$$
\begin{aligned}
& \operatorname{Gold}_{\mathrm{TL}}=\sum_{j=1}^{5} A_{11} \cdot \text { Gold }_{t-j}+\sum_{j=1}^{5} A_{11} \cdot \text { CPI }_{t-j}+E_{1 t} \\
& \mathrm{CPI}=\sum_{j=1}^{5} A_{21} \cdot C P I_{t-j}+\sum_{K=1}^{5} A_{21} \cdot \text { Gold }_{t-j}+E_{2 t}
\end{aligned}
$$

Table 5

Granger Causality Test

\begin{tabular}{ll}
\hline \multicolumn{1}{c}{ Gold to CPI } & \multicolumn{1}{c}{ CPI to Gold } \\
\hline$\chi^{2}=7.84(0.16)$ & $\chi^{2}=20.60(0.001)$ \\
Result: Gold does not Granger Cause of CPI) & Result: CPI does Granger Cause of Gold \\
\hline
\end{tabular}

Note. parentheses shows Probability value.

According to Table 5 there is causality from CPI to gold prices. While there is not causality from gold to CPI. This result is consistent with short run result of eq(3) that there is a positive short run relationship from CPI to gold price.

For clear understanding we applied to short run methodology of S-matrix of Structural VAR (SVAR) of (RUBIO-RAMÍREZ et al., 2010) and also for the long run we employ F-matrix of Structural VAR (SVAR) which proposed by (Blanchard \& Quah, 1989): F- matrix and Smatrix of Structural VAR (SVAR) are as follows:

$$
S_{\text {matrix }}=\left(\begin{array}{cc}
1.30 & -2.04 \\
240.5 & 92.2
\end{array}\right), \quad F_{\text {matrix }}=\left(\begin{array}{cc}
-145.4 & 0.00 \\
-1913.6 & 6686.2
\end{array}\right)
$$

The results of structural VAR to Response of CPI on Gold Price and Gold price on inflation are summarized in Table 6:

Table 6

Results of Impulse Response Test

\begin{tabular}{c|c|c}
\hline Period & Response of inflation to gold: & Response of gold to inflation: \\
\hline \multirow{2}{*}{1} & 0.000000 & 51.57960 \\
& $(0.00000)$ & $(21.1057)$ \\
\hline 2 & 0.510156 & 2.799746 \\
\hline
\end{tabular}




\begin{tabular}{c|c|c}
\hline & $(0.21578)$ & $(37.1703)$ \\
\hline \multirow{2}{*}{3} & 0.952569 & -82.22153 \\
& $(0.40118)$ & $(46.9967)$ \\
\hline \multirow{2}{*}{4} & 0.770014 & -90.04861 \\
& $(0.48146)$ & $(54.6896)$ \\
\hline \multirow{2}{*}{5} & 0.696210 & -82.58811 \\
& $(0.52554)$ & $(60.9165)$ \\
\hline \multirow{2}{*}{6} & 0.850579 & -78.77009 \\
& $(0.56378)$ & $(63.7273)$ \\
\hline \multirow{2}{*}{7} & 0.808190 & -47.10862 \\
& $(0.53893)$ & -21.49568 \\
\multirow{2}{*}{8} & 0.830054 & $(55.7133)$ \\
\hline \multirow{2}{*}{9} & $(0.52024)$ & -18.72752 \\
& 1.035664 & $(52.1854)$ \\
\hline \multirow{2}{*}{10} & $(0.53235)$ & -14.24713 \\
& 1.137991 & $(49.1627)$ \\
\hline
\end{tabular}

According to results of impulse-response of SVAR, response of gold price to inflation in first 2 period is positive and response just in first period is statistically significant. While inflation responds to gold positively but just in three period is statistically significant. To sum up, there is not long run relationship between gold price and inflation in Turkey. While there is short run and causality from CPI to gold price.

\section{Conclusion and Policy Implications}

In this paper, we investigate empirically whether there is short and long run relationship between inflation (consumer price index) and the price of gold in Turkey or not. For this goal, we applied methodologies such as cointegration, causality and Structural VAR by using monthly data over the period of $2008 \mathrm{~m} 10-2021 \mathrm{~m} 04$. We show that there is no long run and cointegration between inflation and the price of gold in Turkey. Although Granger casualty test shows one side casualty from CPI to gold price, there is not casualty from gold to CPI. For clear understanding, we applied to short-run of S-model and the long-run properties of the accumulated impulse responses of structural VAR (SVAR) model. The results of SVAR indicate that there is not generally any interaction between the variable except beginning of the period which it is not statistically important. We expect that this study can of interest to investors and economic policy makers and academicians. The findings of this study suggest policy that gold can not be a gold tools to hedge inflation in selected period. It is likely because of high dollarized in Turkey especially during the last years. From the perspective of policy makers, this paper provides a suggestion that gold is not effective tool against inflation. 


\section{References}

Anandasayanan, S., Thevananth, J., \& Amaresh, M. (2019). The Relationship Between Inflation and Gold Price: Evidence From Sri Lanka (SSRN Scholarly Paper ID 3763419). Social Science Research Network. https://papers.ssrn.com/abstract=3763419

Bampinas, G., \& Panagiotidis, T. (2015). Are gold and silver a hedge against inflation? A two century perspective. International Review of Financial Analysis, 41, 267-276. https://doi.org/10.1016/j.irfa.2015.02.007

Batten, J. A., Ciner, C., \& Lucey, B. M. (2014). On the economic determinants of the goldinflation relation. Resources Policy, 41, 101-108. https://doi.org/10.1016/j.resourpol.2014.03.007

Baur, D. G., \& McDermott, T. K. (2010). Is gold a safe haven? International evidence. Journal of Banking \& Finance, 34(8), 1886-1898. https://doi.org/10.1016/j.jbankfin.2009.12.008

Blanchard, O. J., \& Quah, D. (1989). The Dynamic Effects of Aggregate Demand and Supply Disturbances. The American Economic Review, 79(4), 655-673.

Chua, J., \& Woodward, R. S. (1982). Gold as an Inflation Hedge: A Comparative Study of Six Major Industrial Countries. Journal of Business Finance \& Accounting, 9(2), 191-197. https://doi.org/10.1111/j.1468-5957.1982.tb00985.x

Engle, R. F., \& Granger, C. W. J. (1987). Co-Integration and Error Correction: Representation, Estimation, and Testing. Econometrica, 55(2), 251. https://doi.org/10.2307/1913236

Hoang, T. H. V., Lahiani, A., \& Heller, D. (2016). Is gold a hedge against inflation? New evidence from a nonlinear ARDL approach. Economic Modelling, 54, 54-66. https://doi.org/10.1016/j.econmod.2015.12.013

Iqbal, J. (2017). Does gold hedge stock market, inflation and exchange rate risks? An econometric investigation. International Review of Economics \& Finance, 48, 1-17. https://doi.org/10.1016/j.iref.2016.11.005

Jastram, R. W. (1977). The Golden Constant. https://www.e-elgar.com/shop/gbp/the-goldenconstant-9781847202611.html

Jastram, R. W., \& Leyland, J. (2009). The Golden Constant: The English and American Experience 1560-2007. . Edward Elgar Publishing, London.

Kalsum, U., Hidayat, R., \& Oktaviani, S. (2021). The Effect of Inflation, Interest Rates and World Oil Prices on Gold Prices in Indonesia with the US Dollar Exchange Rate as an Intermediary Variable. International Journal of Finance Research, 2(1), Article 1. https://doi.org/10.47747/financeinvestmentderivative.v2i1.228 
Lucey, B. M., Sharma, S. S., \& Vigne, S. A. (2017). Gold and inflation(s) - A time-varying relationship. Economic Modelling, 67, 88-101. https://doi.org/10.1016/j.econmod.2016.10.008

Mahdavi, S., \& Zhou, S. (1997). Gold and commodity prices as leading indicators of inflation: Tests of long-run relationship and predictive performance. Journal of Economics and Business, 49(5), 475-489. https://doi.org/10.1016/S0148-6195(97)00034-9

Moore, G. H. (1990). Analysis: Gold Prices and a Leading Index of Inflation. Challenge, 33(4), 52-56. https://doi.org/10.1080/05775132.1990.11471444

Narayan, P. K., Narayan, S., \& Sharma, S. S. (2013). An analysis of commodity markets: What gain for investors? Journal of Banking \& Finance, 37(10), 3878-3889.

Narayan, P. K., Narayan, S., \& Zheng, X. (2010). Gold and oil futures markets: Are markets efficient? Applied Energy, 87(10), 3299-3303. https://doi.org/10.1016/j.apenergy.2010.03.020

Ojaghlou, M. (2020). Dynamic Effects of Macroeconomic Fundamentals on Stock Market Movements: Evidence from BIST100 (SSRN Scholarly Paper ID 3762073). Social Science Research Network. https://doi.org/10.2139/ssrn.3762073

Rubio-Ramírez, J. F., Waggoner, D. F., \& Zha, T. (2010). Structural Vector Autoregressions: Theory of Identification and Algorithms for Inference. The Review of Economic Studies, 77(2), 665-696.

Sharma, S. S. (2016). Can consumer price index predict gold price returns? Economic Modelling, 55, 269-278. https://doi.org/10.1016/j.econmod.2016.02.014

Sui, M., Rengifo, E. W., \& Court, E. (2021). Gold, inflation and exchange rate in dollarized economies - A comparative study of Turkey, Peru and the United States. International Review of Economics \& Finance, 71, 82-99. https://doi.org/10.1016/j.iref.2020.08.014

Tkacz, G. (2007). Gold Prices and Inflation. Staff Working Papers, Bank of Canada., 07-35,.

Xu, Y., Su, C.-W., \& Ortiz, J. (2021). Is gold a useful hedge against inflation across multiple time horizons? Empirical Economics, 60(3), 1175-1189. https://doi.org/10.1007/s00181-01901807-0 